\title{
Lignocellulolytic Activities among Trichoderma Isolates from Lahad Datu, Sabah and Deception Island, Antarctic
}

\author{
Nur Shafawati Saili ${ }^{1}$, Shafiquzzaman Siddiquee ${ }^{1 *}$, Clemente Michael Wong Vui Ling ${ }^{1}$, Marcelo González ${ }^{2}$ and S Vijay Kumar ${ }^{1}$ \\ ${ }^{1}$ Biotechnology Research Institute, Universiti Malaysia Sabah, Jalan UMS, 88400 Kota Kinabalu, Sabah, Malaysia \\ ${ }^{2}$ Instituto Antártico Chileno, Plaza Muñoz Gamero 1055, Punta Arenas, Chile
}

\begin{abstract}
Trichoderma species have the potential for application in composting as biological control agents in controlling disease and increasing yield of production in the agricultural industry. The prevalent soil fungus of Trichoderma produces lignocellulolytic enzymes that assist the degradation of woody lignocellulose materials. The aim of the experimental work was to check the potential of lignocellulolytic Trichoderma fungi for the use of rapid composting of oil palm empty fruit bunches fibers. Fifty-two of Trichoderma isolates from Sabah and seven isolates from Antarctic were examined for in-vitro lignocellulolytic activity by assaying their ability to develop dark brown pigments, yellow halo zone, and clear white zone on tannic acid media (TAM) for lignin; Jensen Media (JM) for cellulose; and modified Melin-Nokrans media (MMNM) for starch. The best six Sabah Trichoderma isolates (5D, 10L2, 10P, 5E, 10X, and 10E2) were found to be potential lignocellulolytic agents based on their diameter of halo zone formed on amended media for further testing of in vitro bioconversion of oil palm empty fruit bunches. The diameters of halo zones were measured for the analysis of their ability in degrading lignin, cellulose, and starch. In contrast, Antarctic Trichoderma isolates consistently exhibited lower lignocellulolytic activities based on their smaller diameter of halo zone formed on TAM, JM, and MMNM. Most of the Trichoderma isolates are found to synthesize polyphenol oxidase, endoglucanases, and are able to hydrolyze starch to glucose in the three different media. Thus, the finding shows the potential of these isolates for use in large-scale composting of oil palm empty fruit bunches.
\end{abstract}

Keywords: Lignocellulolytic; Genus Trichoderma; Oil palm empty fruit bunches; Antarctic

\section{Introduction}

Biomass can be divided into three categories-namely, wood and agricultural products, solid waste and landfill gas, and biogas. According to Roslan et al. [1] and EU-Malaysia Biomass Sustainable Production Initiative [2], the biomass industry in Malaysia has represented renewable organic matters, including timber waste, rice husk, coconut trunk fibers, sugar cane waste, municipal solid waste, and oil palm waste. These biomasses exhibit potential in the manufacturing of valueadded products such as bio-plastics, bio-composites, bio-pellets, and bio-fertilizers.

Statistics released by MPOB [3] show that Malaysia has the largest planted areas of oil palm trees in the world which occupy approximately 4.5 million ha of oil palm plantation areas. Consequently, the amounts of biomass wastes generated by this industry are abundant. In 2011, oil palm industries in Malaysia produced approximately 80 million tons of dry weight of oil palm biomass [4]. Only $10 \%$ of the oil palm tree consists of crude palm oil, and the remaining are lignocellulosic wastes which includes the trunks, fronds, palm-pressed fibers, and empty fruit bunches [5]. Hence, these products are not only under-utilized but also frequently cause pollution [6].

Composting is one of the potential ways to reduce these bio-wastes by converting them to bio-fertilizer. However, composting is always labeled as a time-consuming process owing to the wooden structure of the bio-masses. The conventional style of composting through natural degradation is slow and is not applicable to some lignocellulose materials. With the advances in biotechnology, the composting process can be accelerated. Dayana Amirah et al. [7] have shown that the soil fungus $T$. virens exhibits the best degrader of organic matter to minerals. Based on their results, the application of Trichoderma to the bio-waste can shorten the composting period. A consortium of effective microbes that contribute efficiently in composting process can be formulated by the inclusion Trichoderma spp. that has the ability to degrade lignocellulose materials effectively. Microorganisms to form the effective microbes consortium are selected and identified through a few selection processes with special focus on their ability to degrade lignocellulose materials.

A natural degrader of lignocellulosic materials, Trichoderma species also possesses acted as a biological control agent. It exerts strong competitive effects of space and nutrients, produces toxins against phytopathogenic species [8], and has antagonist properties toward Ganoderma boninense [9].

Definitions on lignocellulolytic enzymes have been provided by Mtui [10] and state that the biocatalysts are responsible for the degradation of lignocellulosic (lignin and cellulosic) materials. Lignocellulolytic fungi have a potential to degrad a range of the lignocellulosic biomass, including recalcitrant and highly toxic phenolic compounds. It possesses diverse, profitable bio-products used in industrial applications, including food, textile, pulp, paper and others [10].

Studies on cellulolytic activities are well-described by Biswas

*Corresponding authors: Shafiquzzaman Siddiquee, Biotechnology Research Institute, Universiti Malaysia Sabah, Jalan UMS, 88400 Kota Kinabalu Sabah, Malaysia, Tel: +6088-320000 ext. 8467; Fax: +6088-320993; E-mail: shafiqpab@ums.edu.my, shafiq.siddiquee@gmail.com

Received June 20, 2014; Accepted July 05, 2014; Published July 11, 2014

Citation: Saili NS, Siddiquee S, Vui Ling CMW, González M, Vijay Kumar S (2014) Lignocellulolytic Activities among Trichoderma Isolates from Lahad Datu, Sabah and Deception Island, Antarctic. J Microb Biochem Technol 6: 295-302. doi:10.4172/1948-5948.1000159

Copyright: ( 2014 Saili NS, et al. This is an open-access article distributed under the terms of the Creative Commons Attribution License, which permits unrestricted use, distribution, and reproduction in any medium, provided the original author and source are credited 
and Narayanasamy [11]; the inclusion of T. virens to the bio-waste promotes rapid degradation of cellulose and hemicelluloses, and it showed great potential by shortening the period of composting. The composting process is shortened to one month when Aspergillus and Trichoderma were added.

Sabah is the second largest state in Malaysia, and it is situated in the Island of Borneo and shares the borders with Sarawak, Brunei, and Indonesian Kalimantan. With an area spanning 72,500 square kilometers, lined with beaches surrounded by the South China Sea to the west, the Sulu Sea in the northeast, and the Celebes Sea in the East, Sabah is located in the northern portion of Borneo. Most of the landscapes in Sabah are lowland rain forests with areas of mountain rain forests. Climate throughout the state is equatorial/tropical with an estimated temperature of $32^{\circ} \mathrm{C}\left(90^{\circ} \mathrm{F}\right)$ in the lowlands and an average temperature of $21^{\circ} \mathrm{C}\left(70^{\circ} \mathrm{F}\right)$ in the highlands. Sabah is the sole producer of palm oil and cocoa in Malaysia, and Lahad Datu is the location where oil palms are extensively farmed in Sabah [12]. Lahad Datu is located in southeastern Sabah, bordered with the Kinabatangan district in the northeast; whereas Kunak, Semporna, and Tawau are located in the south. Oil palm plantations cover approximately 700,000 ha in the East Coast area and they have contributed toward almost $25 \%$ of the crude palm oil exports of the country [13].

In contrast, Antarctic is the driest, coldest, and windiest place in the world with the lowest temperature of Vostok recorded $\left(-89.2^{\circ} \mathrm{C}\right)$ in 1983 . Most of Antarctic is covered with ice that is more than 1.6 kilometers thick [14]. In short, any microorganism lives in Antarctic under the most extreme condition-between the limit of adaptability and near death, barely surviving, and rarely reproduced [15]. Nevertheless, some researchers have revealed the existence of Trichoderma in Antarctic that are isolated from different places; namely, Trichoderma atroviride by Holker et al. [16], T. koningii by Hughes et al. [17], T. asperellum by Ren et al. [18], and T. citinoviride by Jacklitsch [19]. The lignocellulolytic activities of tropical and Antarctic fungi are significantly different based on the studies done by some researchers [20-23]. Tropical fungi show different, unique metabolites owing to having a distinct metamorphosis and adaptability when compared with their other temperate counterparts [10]. Therefore, the aim of this study was to compare the lignocellulolytic activities between Trichoderma isolates from tropical areas of Sabah and those from extremely cold area in Antarctic.

\section{Materials and Methods}

\section{Isolation of lignocellulytic fungi}

Trichoderma isolates were isolated from soil samples collected from Ladang Sahabat 33 oil palm plantations, Kinabatangan, Lahad Datu, Sabah (Figure 1) and the Deception Island soil-rock (Craters Lake S62 $58^{\prime} 56.34^{\prime \prime}, \mathrm{W} 60^{\circ} 39^{\prime} 51.10^{\prime \prime}$ and Soto Lake S62 $59^{\prime} 01.96^{\prime \prime}$ W60 $\left.39^{\prime} 13.21^{\prime \prime}\right)$, Antarctica. The soil samples were mixed homogeneously before $10 \mathrm{~g}$ was weighed out and put into a flask; after that, $100 \mathrm{ml}$ of sterilized distilled water $\left(121^{\circ} \mathrm{C} / 1.05 \mathrm{~kg} / \mathrm{m}^{2}\right.$ for $\left.15 \mathrm{~min}\right)$ was added to make the stock solution following the method of Elad et al. [24]. A stock solution of $10 \mathrm{~g}$ soil in $100 \mathrm{ml}$ of sterile distilled water solution was placed on an environmental orbital shaker that was set at $210 \mathrm{rpm}$ for $20 \mathrm{~min}$, after which $1 \mathrm{ml}$ solution was added to $9 \mathrm{ml}$ of water first for the first $\left(10^{-1}\right)$ dilution. From preliminary trials, the serial dilutions at $10^{-3}$ and $10^{-5}$ were used for the Colony Forming Unit (CFU) estimation. One $\mathrm{ml}$ of soil solution was pipetted out and seeded into each Petri dish followed by pouring $9 \mathrm{ml}$ of sterilized Trichoderma Selective Medium (TSM) [0.20 g of $\mathrm{MgSO}_{4} .7 \mathrm{H}_{2} \mathrm{O}, 0.90 \mathrm{~g}$ of $\mathrm{K}_{2} \mathrm{HPO}_{4}$,

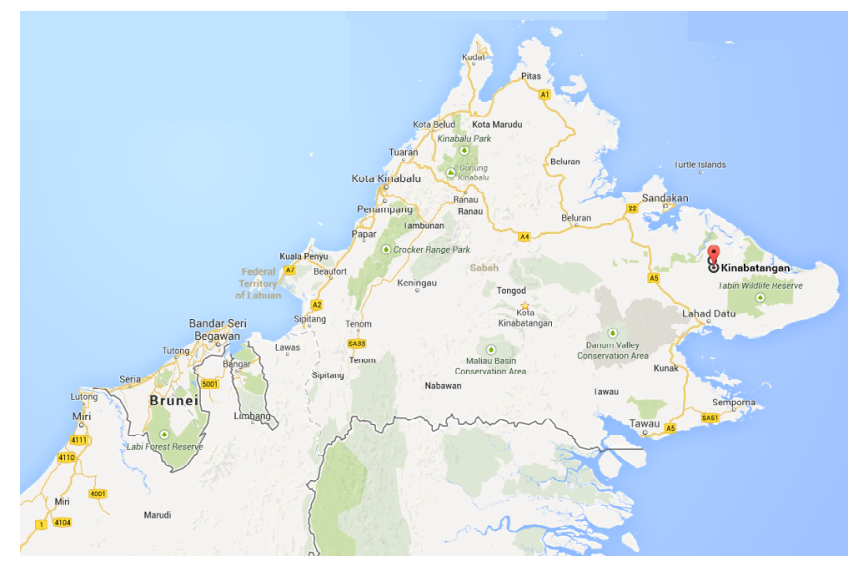

Figure 1: Sample collection site of Trichodemera species in this study.

$0.15 \mathrm{~g}$ of $\mathrm{KCl}, 1.0 \mathrm{~g}$ of $\mathrm{NH}_{4} \mathrm{NO}_{3}, 3.0 \mathrm{~g}$ of glucose, $0.15 \mathrm{~g}$ of Rose Bengal, $20.0 \mathrm{~g}$ of agar (Difco, USA), and $1000 \mathrm{ml}$ of distilled water] [24]. The Petri dish was swirled manually before solidification and incubated at $28 \pm 2{ }^{\circ} \mathrm{C}$. After a 7 day incubation period, fungal colonies could be seen as small whitish growth spots. Each single colony richly appeared on the plate and then was scored as a Colony Forming Unit (CFU). All Colony Forming Units (CFU) appeared per plate and were then checked and re-isolated onto fresh potato dextrose agar (PDA) (Oxoid, UK). Subcultures and pure cultures were maintained on PDA slants in universal bottles and maintained from 4 to $10^{\circ} \mathrm{C}$ at the Biotechnology Research Institute until they were required for further studies.

Enzymatic degradation on the basis of the lignocellulolytic activities between Trichoderma isolates was observed throughout the biochemical screening process. In this screening process, three types of enzymatic activities were tested-degradation of lignin, cellulose, and starch. Three replicate plates were done for each treatment, and the experiment was repeated twice under room temperature conditions $\left(28 \pm 2^{\circ} \mathrm{C}, 12 \mathrm{~h}\right.$ daylight and $12 \mathrm{~h}$ darkness).

\section{Morphological characterization}

Pure cultures of Trichoderma were aseptically cultured from stock slants onto agar medium in the Petri dishes. All isolates were allowed to sporulate under room temperature. Mycelium was typically formed within three to four days as compact or loose tufts in shades of green, yellow, or, less frequently, white. A yellow pigment was secreted into the agar. All isolate observations were recorded especially on PDA medium. Radial growth of the Trichoderma colony on PDA medium was observed daily until the plate was completely covered. Pure cultures were transferred onto a new PDA medium for characterization into species aggregates.

For microscopic examination, $5 \mathrm{~mm}$ of mycelia was cut from the culture and transferred onto a sterile glass slide with an inoculation needle. The slides were viewed under a light biological microscope (Olympus CX31), and photographs were taken with a camera that was attached to the microscope and connected to a computer. A 40x magnification lens was used to observe conidia, conidiophores, hyphae, chlamydospores, and phialides for the selection of the Trichoderma species. A conidiophore was a simple/or branched fertile hypha in which conidia were produced. Phialides were observed for their appearance, which was flask like or bowling pins shaped. The cultures 
Citation: Saili NS, Siddiquee S, Vui Ling CMW, González M, Vijay Kumar S (2014) Lignocellulolytic Activities among Trichoderma Isolates from Lahad Datu, Sabah and Deception Island, Antarctic. J Microb Biochem Technol 6: 295-302. doi:10.4172/1948-5948.1000159

were also observed for the presence of chlamydospores that were often thickened hyaline cells.

\section{Lignocellulolytic activities of Trichoderma isolate}

Enzymatic degradation of lignin: Enzymatic degradation of lignin was tested according to the Thormann et al. [25] method with some necessary modifications. Tannic acid media (TAM) $[5.0 \mathrm{~g}$ tannic acid, $15.0 \mathrm{~g}$ malt extract agar (Difco, USA), $20.0 \mathrm{~g}$ agar (Difco, USA), and $1000 \mathrm{ml}$ of distilled water] was autoclaved at $121^{\circ} \mathrm{C} / 1.05 \mathrm{~kg} / \mathrm{m}^{2}$ for 15 min and poured into petri dishes at $20 \mathrm{ml}$ per plate. A $5.0-\mathrm{mm}$ diameter agar disc cut out from the leading edge of 5 day old pure culture of each Trichoderma isolate was placed at the center of each TAM plate, then incubated at $28 \pm 2^{\circ} \mathrm{C}$, and kept in complete darkness for 4 days. Lignin degradation was determined through the formation of dark brown pigments as an indicator of polyphenol oxidase (PPO) activity in the inoculation area.

Enzymatic degradation of cellulose: The fibrolytic ability of the fungi was tested on Jensen media [26] [20.0 g of sucrose, $1.0 \mathrm{~g}$ of $\mathrm{K}_{2} \mathrm{HPO}_{4}, 0.1 \mathrm{~g}$ of $\mathrm{FeSO}_{4}, 0.5 \mathrm{~g}$ of $\mathrm{MgSO}_{4} .7 \mathrm{H}_{2} \mathrm{O}, 0.5 \mathrm{~g}$ of $\mathrm{NaCl}, 0.005 \mathrm{~g}$ of $\mathrm{NaMoO}_{4}, 2.0 \mathrm{~g}$ of $\mathrm{CaCO}_{3}, 15.0 \mathrm{~g}$ of agar, and $2.0 \mathrm{~g}$ of Carboxymethyl Cellulose (CMC)] and autoclaved at $121^{\circ} \mathrm{C} / 1.05 \mathrm{~kg} / \mathrm{m}^{2}$ for $15 \mathrm{~min}$. After that, $20 \mathrm{ml}$ of media was poured into each petri dish. Five day old pure cultures of Trichoderma mycelia were cut by using a $5 \mathrm{~mm}$ disc cork-borer, then placed at the center of each media plate, and allowed to grow for 7 days at $28 \pm 2^{\circ} \mathrm{C}$. Congo red $(1.0 \mathrm{mg} / \mathrm{ml})$ and $1.0 \mathrm{M}$ of $\mathrm{NaCl}$ solutions were used to make contact with the colony for $15 \mathrm{~min}$ and then poured away. The yellowish halo zones surrounding the inoculation area appeared and were immediately measured for the analysis of cellulose hydrolysis according to Teather and Wood [27] protocol.

Enzymatic degradation of starch: Degradation of starch was examined through the appearance of halo zone. Modified MelinNokrans Media (MMNM) [1.0 g of D-glucose anhydrous, $2.0 \mathrm{~g}$ of malt extract agar (Difco, USA), $1.0 \mathrm{~g}$ of yeast extract, $10.0 \mathrm{~g}$ of $\mathrm{KH}_{2} \mathrm{PO}_{4}, 5.0 \mathrm{~g}$ of $\left(\mathrm{NH}_{4}\right) \mathrm{HPO}_{4}, 3.0 \mathrm{~g}$ of $\mathrm{MgSO}_{4} .7 \mathrm{H}_{2} \mathrm{O}, 1.0 \mathrm{~g}$ of $\mathrm{CaCl}_{2}, 0.5 \mathrm{~g}$ of NaCl, 12.0 $\mathrm{g}$ of agar (Difco, USA), and $1000 \mathrm{ml}$ of distilled water] along with 2.0 $\mathrm{g}$ of soluble starch $[25,28]$ were autoclaved at $121^{\circ} \mathrm{C} / 1.05 \mathrm{~kg} / \mathrm{m}^{2}$ for 15 min and poured into petri dishes at $20 \mathrm{ml}$ per plate. A $5 \mathrm{~mm}$ diameter of pure Trichoderma culture on MMNM was grown for 3 days at 28 $\pm 2^{\circ} \mathrm{C}$. After that, the cultures were flooded with iodine solution $[5.0$ $\mathrm{g}$ of $\mathrm{KI}, 1.5 \mathrm{~g}$ of I, and $100 \mathrm{ml}$ of $\mathrm{ddH}_{2} \mathrm{O}$ ] for $5 \mathrm{~min}$ and decanted. A clear white zone indicated the hydrolyzed starch and exhibited amylase enzymatic activity.

\section{Data analysis}

Statistical analyses of data were performed by using the Statistical Package for the Social Science (SPSS), version 21.0. One way analysis of variance (ANOVA) was carried out to show the significance difference at $\mathrm{p} \leq 0.05$. Tukey test was used to compare the means.

\section{Results}

\section{Isolation of Trichoderma on TSM}

Total number Trichoderma colonies seen on the agar plates were considered based on the CFU for four days during the incubation period. A total of 97 Trichoderma colonies were obtained from the soil samples taken from Sabah, and seven colonies were obtained from the soil samples taken from Antarctic. The soil samples from Sabah and Antarctic were found to be roughly $70 \%$ of Trichoderma CFU on TSM.
Penicillium sp., Aspergillus sp., and unidentified fungi were also found in TSM (Table 1).

\section{Enumeration and characterization of Trichoderma isolates}

Trichoderma colonies on TSM were seen as white specks on agar plates; after that, they were enlarged by at least 5 to $6 \mathrm{~mm}$ within 6 days. By this time, the white colony turned yellowish/greenish/gray/off white on TSM (Figure 2). Trichoderma colonies rapidly grew and developed a green-yellow color. This feature was different from other fungi and also facilitated the identification of Trichoderma. A total of 97 Trichoderma $\mathrm{CFU}$ was cultured from 15 sampling points.

Subculture was done on a PDA medium; Trichoderma was initially white and after two days, it turned slightly green. At the moment, the wooly conidia filled up and were compact at the midpoint of a Petri dish with mostly dark green color. Usually, on the $4^{\text {th }}$ and $5^{\text {th }}$ days, $50-60 \%$ of the colonies appeared dark green, whereas the remaining $40-50 \%$ of the area was dull green/or off white depending on the species (Figures 3 and 4). The back of the colonies was mostly light green, dull, pale, and off white in color owing to the fluctuation in the species. Some of the Trichoderma remained a slightly green/yellow/white color owing to the species variations (Figure 4).

Microscopic examinations were conducted on the conidiophores that typically formed paired branches and displayed pyramidals arranged along the length of the primary axis (Figures 3 and 4). Branches toward the top and secondary branches tended to be held at $90^{\circ}$ to the main axis formed, which they grew. Variations were seen in the phialides-typically enlarged in the middle; long, skinny shaped, bottle shaped, flask shaped, inflated at the based, and some were cylindrical. Phialides were held in the whorls that were commonly flask shaped, densely clustered on a wide main axis.

\section{Lignocellulolytic activities of Trichoderma isolate}

Enzymatic degradation of lignin: Most of the Trichoderma isolates exhibited multiple capabilities in degrading lignin. Forty three out of 52 Sabah Trichoderma isolates and all the Antarctic Trichoderma isolates were able to put out the polyphenol oxidase (Figures 5 and 6). Six Sabah isolates were found to have larger brown pigment diameter values of $4.93 \mathrm{~cm}$ for isolate $5 \mathrm{D}, 4.43 \mathrm{~cm}$ for isolate $10 \mathrm{~L} 2,4.43 \mathrm{~cm}$ for isolate 10P, $4.27 \mathrm{~cm}$ for isolate $5 \mathrm{E}, 4.20 \mathrm{~cm}$ for isolate $10 \mathrm{X}$, and $4.13 \mathrm{~cm}$ for isolate $10 \mathrm{E} 2$, respectively (Figure 7). The ligninolytic activities of the Antarctic Trichoderma isolates were always lower when compared with Sabah Trichoderma isolates (Figure 6). Most of the Trichoderma isolates produced a dark brown zone halo with a diameter of more than $2 \mathrm{~cm}$ (Figures 5 and 6).

Enzymatic degradation of cellulose: All the Trichoderma isolates

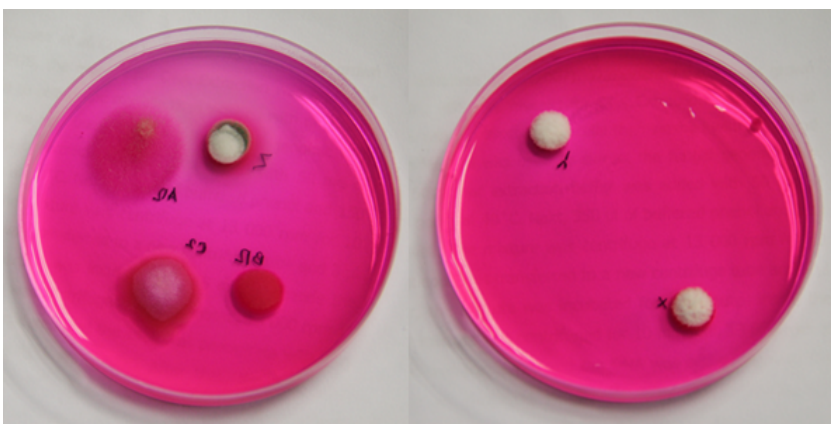

Figure 2: Five-day-old culture showing Trichoderma CFU on TSM. 
Citation: Saili NS, Siddiquee S, Vui Ling CMW, González M, Vijay Kumar S (2014) Lignocellulolytic Activities among Trichoderma Isolates from Lahad Datu, Sabah and Deception Island, Antarctic. J Microb Biochem Technol 6: 295-302. doi:10.4172/1948-5948.1000159

\begin{tabular}{|c|c|c|c|}
\hline Soil Samples & No. of Trichoderma CFU & Other Fungi & Percentage of Trichoderma CFU \\
\hline Lahad Datu, Sabah & 97 & 2 (Aspergillus sp.), 39 (Penicillium sp. and other fungi) & 70 \\
\hline Graham Land, Antarctic & 7 & 3 (Penicillium sp.) \\
\hline
\end{tabular}

Table 1: Trichoderma colonies are counted among all soil samples.
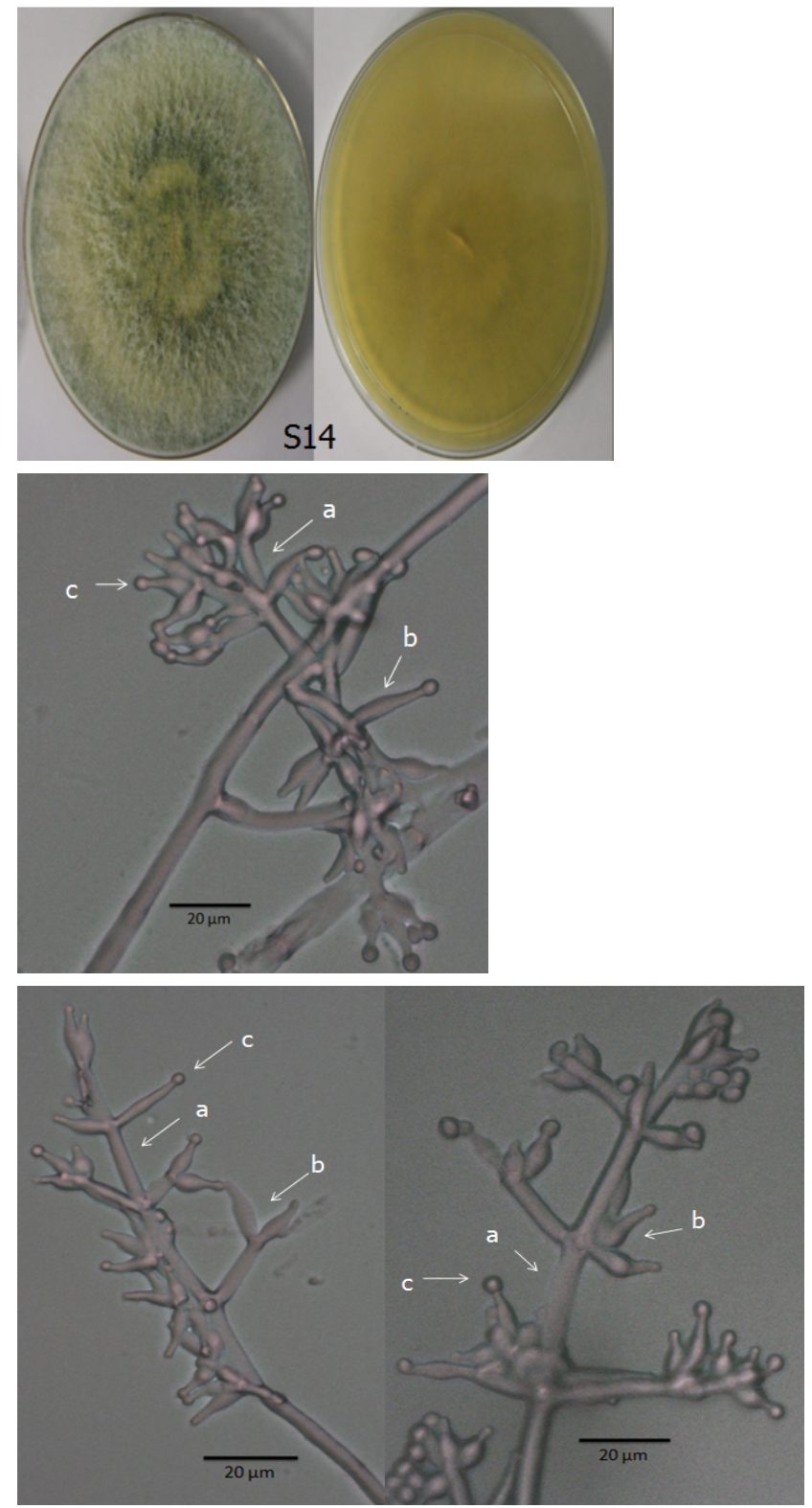

Figure 3: Cultural and morphological characteristic of Trichoderma isolate named S14 isolated from Sabah; (a) conidiophores (b) phialide (c) conidia.

from Sabah and Antarctic were able to degrade the cellulose (Figure 8). Cellulose degradation variations were seen in the results shown in Figures 5 and 6. All Sabah Trichoderma isolates were able to hydrolyze cellulose as indicated in Figure 5. Seven isolates were found to have higher cellulolytic activity values of $2.53 \mathrm{~cm}$ for $1 \mathrm{gB}, 2.50 \mathrm{~cm}$ for 1 $\mathrm{gE}, 2.36 \mathrm{~cm}$ for $1 \mathrm{gF}, 2.33 \mathrm{~cm}$ for SIC, $2.33 \mathrm{~cm}$ for CI, $2.30 \mathrm{~cm}$ for $11 \mathrm{~A}$, and $2.30 \mathrm{~cm}$ for SIE, respectively. The isolate $1 \mathrm{gB}$ was found to have a significantly $(\mathrm{p} \leq 0.05)$ higher clearing zone diameter. In comparison, the cellulolytic activities of the Antarctic Trichoderma isolates, were
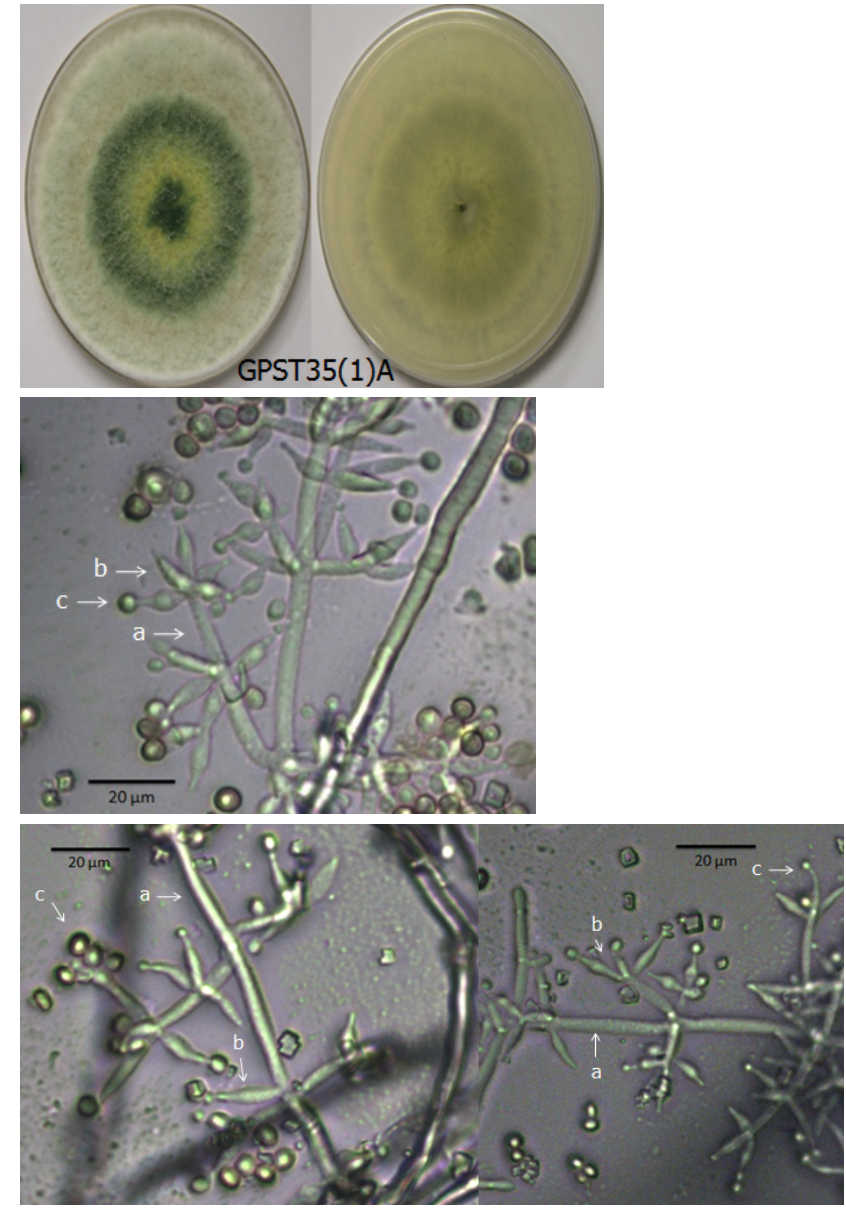

Figure 4: Cultural and morphological characteristic of Trichoderma isolate named GPST35(1)A isolated from Antarctic; (a) conidiophores (b) phialide (c) conidia.

always lower when compared to those from Sabah and their yellowish clearing zone ranged from 1.70 to $2.30 \mathrm{~cm}$ (Figures 5 and 6).

Enzymatic degradation of starch: All Trichoderma isolates (Sabah and Antarctic) were found to be effective in degrading starch (Figures 5,6 and 9). Four Sabah isolates $(7.47 \mathrm{~cm}$ for $10 \mathrm{~L} 2,7.33 \mathrm{~cm}$ for $12 \mathrm{~L}, 6.87$ $\mathrm{cm}$ for $14 \mathrm{~V}$, and $6.17 \mathrm{~cm}$ for $14 \mathrm{U} 2)$ showed a significantly $(\mathrm{p} \leq 0.05)$ higher halo zone diameter when flooded with iodine solution (Figure 5). However, Antarctic Trichoderma isolates exhibited apparently lower amylase activities with the halo zone sizes ranging from 1.53 to $3.90 \mathrm{~cm}$ (Figure 6).

\section{Discussion}

Among all the 33 samples collected from the plantations in Ladang Sahabat and Deception Island 70\% of them harbored Trichoderma species. The Trichoderma isolates were distinguished through their morphological characteristics under the macroscope (color of conidia, sporulation pattern, and density) and microscope (structure 
Citation: Saili NS, Siddiquee S, Vui Ling CMW, González M, Vijay Kumar S (2014) Lignocellulolytic Activities among Trichoderma Isolates from Lahad Datu, Sabah and Deception Island, Antarctic. J Microb Biochem Technol 6: 295-302. doi:10.4172/1948-5948.1000159

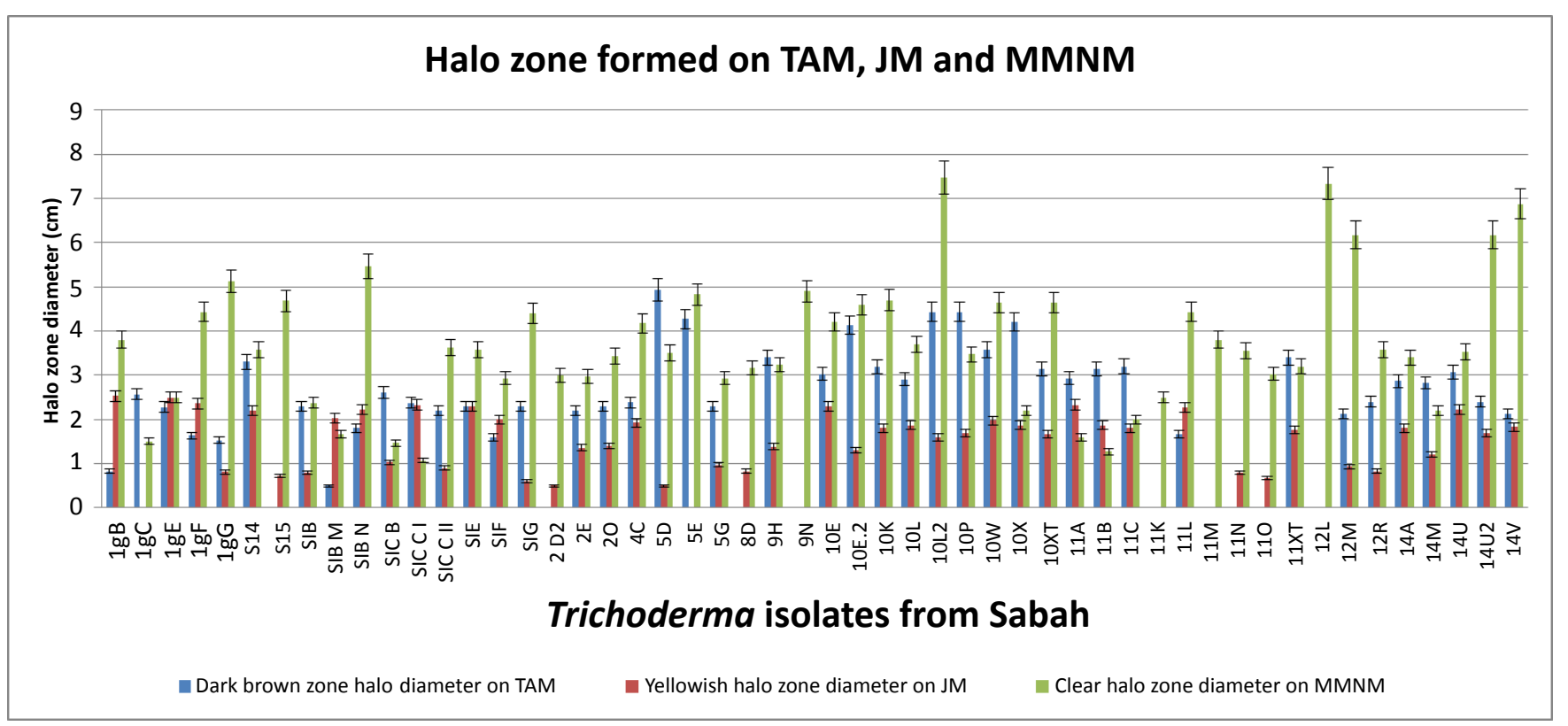

Figure 5: Comparison between Trichoderma isolates from Sabah and Antarctic on their ability to degrade lignin with a large halo zone (isolates $10 \mathrm{X} ; 4.20 \mathrm{~cm}$ (a) and (isolates CRATERSOTOII; $2.17 \mathrm{~cm}$ (c)) and a small halo zone (isolates SIB M; $0.50 \mathrm{~cm}$ and isolates GPST351B; $1.90 \mathrm{~cm}$ (d)).

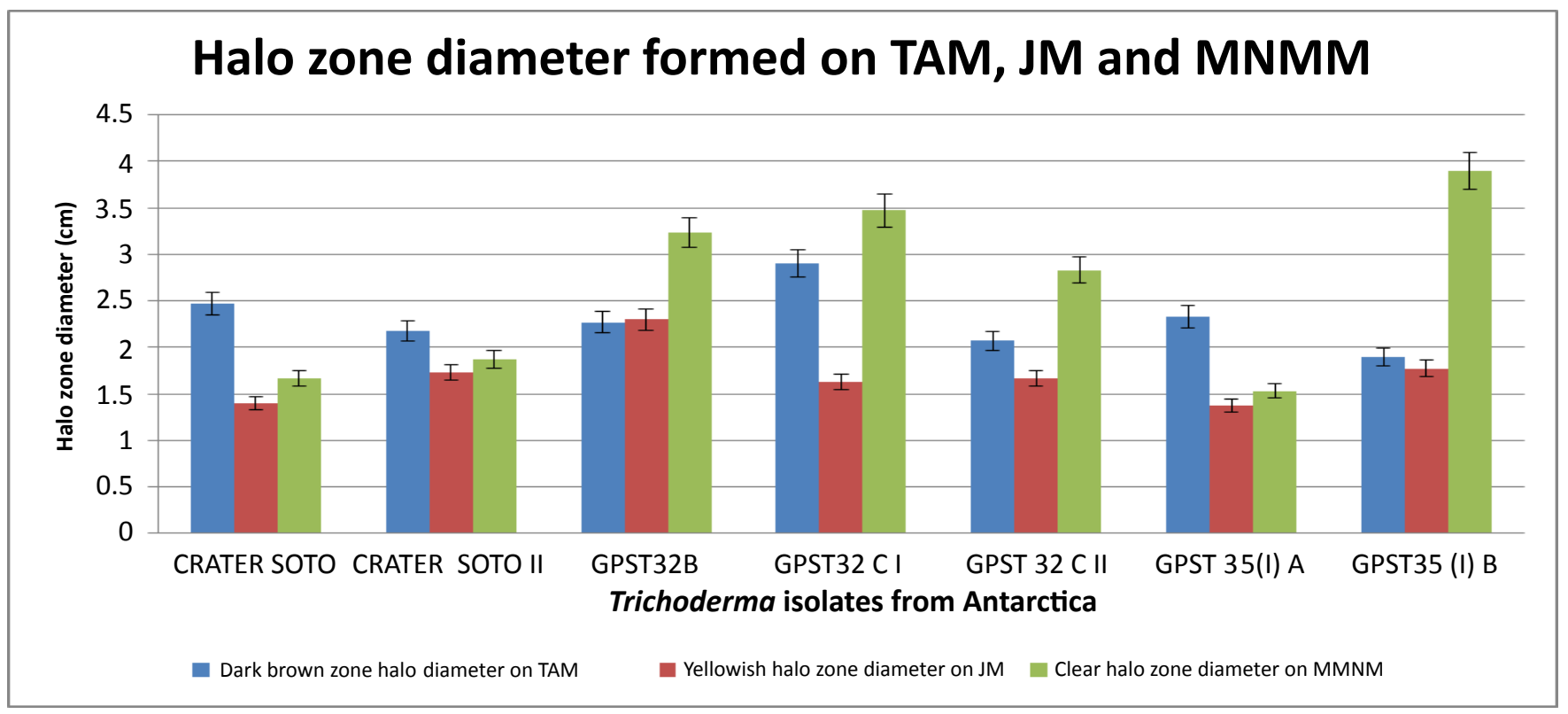

Figure 6: Comparison between Trichoderma isolates from Sabah and Antarctic on their ability to degrade cellulose with a large halo zone (isolate $1 \mathrm{gB} ; 2.53 \mathrm{~cm}$ (a) and isolate GPST32B; $2.30 \mathrm{~cm}(\mathrm{c})$ ) and a small halo zone (isolate 2D; $0.50 \mathrm{~cm}$ (b) and isolate GPST351A; $1.37 \mathrm{~cm}$ (d)).

and arrangement of phialide, conidial size, and shape). However, morphological and cultural characteristics cannot be used to distinguish Trichoderma isolates up to the species level [29]. Similarly, most of the researchers are facing difficulty with regard to the identification of the Trichoderma species owing to the higher level of structural similarities.

The Trichoderma species can be found everywhere in the world, including the area with extreme climate such as the Antarctic. Some researchers $[9,30,31]$ have analyzed the identities of Trichoderma spp. from tropical areas in West Malaysia. However, no in-depth studies are performed on isolates from Borneo Island in East Malaysia. To the best of our knowledge, this is the first time that the Trichoderma species is reported in the Island of Borneo. Isolation of fungi from the Antarctic has reported by several researchers [32-35]. However, only few researchers $[17,36]$ have isolated fungi belonging to the Trichoderma genus. These results show that Trichoderma species may survive in in the harsh Antarctic environment. Johnson et al. [37] have also found Trichoderma species in the soils of Tennessee and Alaska, Canada which have cold climates. Nevertheless, the enzymatic activities of Trichoderma isolates from those cold climates are not characterized. 


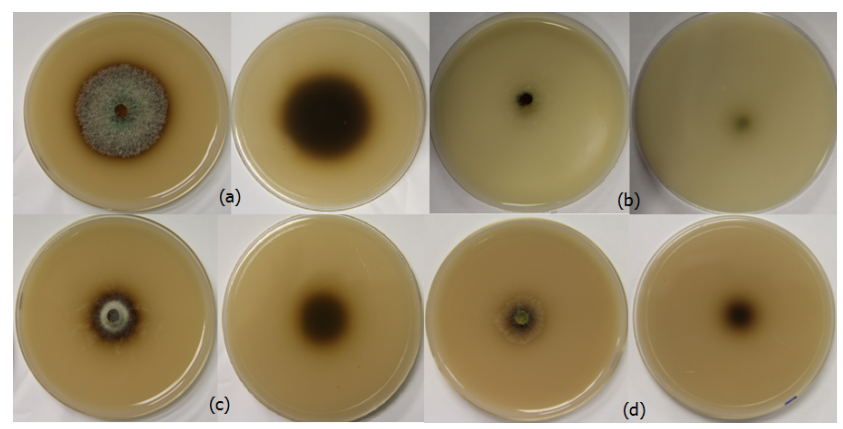

Figure 7: Comparison between Trichoderma isolates from Sabah and Antarctic on their ability to degrade starch with a large halo zone (isolates $14 \mathrm{~V} ; 6.87 \mathrm{~cm} \mathrm{(a)} \mathrm{and} \mathrm{isolates} \mathrm{GPST32B;} 3.23 \mathrm{~cm}(\mathrm{c}))$ and a small halo zone (isolate $5 \mathrm{E} ; 4.83 \mathrm{~cm} \mathrm{(b)} \mathrm{and} \mathrm{isolates} \mathrm{GPST32CII;} 2.83 \mathrm{~cm}(\mathrm{~d})$ ).

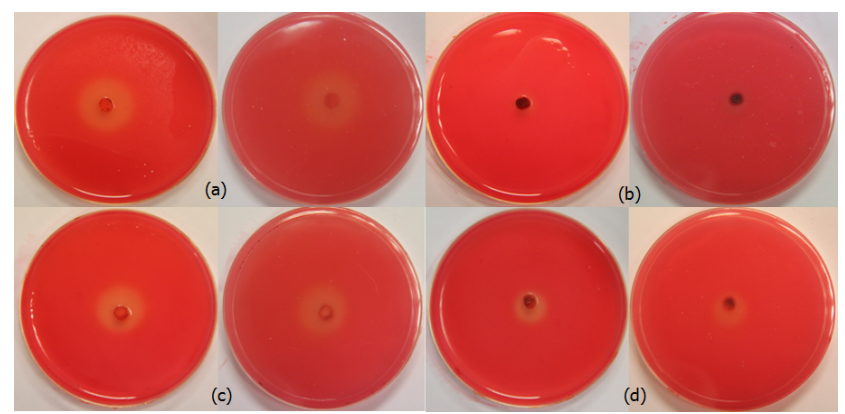

Figure 8: Halo zone diameter recorded for lignin, cellulose, and starch degradation by Trichoderma isolates isolated from Sabah on media containing tannic acid, CMC, and starch.

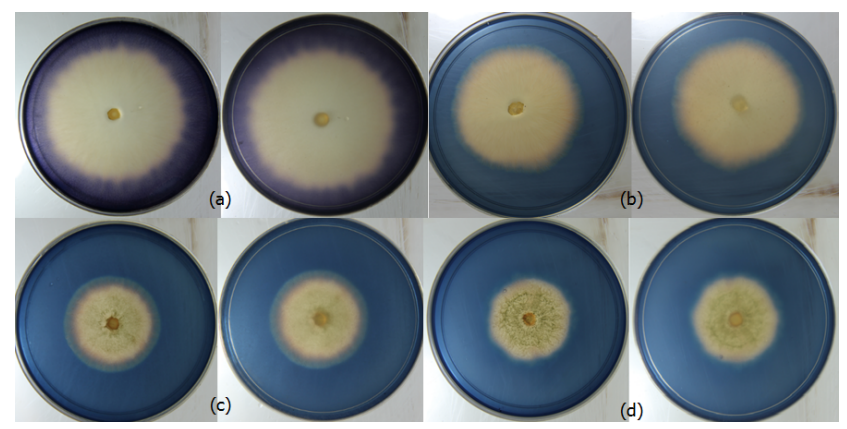

Figure 9: Halo zone diameter recorded for lignin, cellulose, and starch degradation by Trichoderma isolates isolated from Antarctic on media containing tannic acid, CMC, and starch.

All of the comparative studies on the lignocellulolytic activities between the Tropical and Antarctic Trichoderma isolates were conducted at $28 \pm 2^{\circ} \mathrm{C}$. This was possible because both the Sabah and Antarctic's isolates grew well at $28 \pm 2^{\circ} \mathrm{C}$. The comparisons of lignocellulolytic activities of Trichoderma from habitats with different extremes are new and have never been reported by any other researchers. Our results indicated that the Sabah Trichoderma isolated is more suited for composting in the tropical climate. Nevertheless, detection of lignocellulase activities in the Trichoderma isolates from the Antarctic indicating that composting probably can be conducted in temperate regions. In future the Antarctic Trichoderma isolates can be tested for their composting ability in cold areas. So, investigation of the lignocellulolytic activities at a lower temperature is a good idea for conducting some research in the near future.

\section{Enzymatic degradation of lignin}

Priority should be given to the degradation of lignin based on its main structure-encrusting and guarding the cellulose and hemicelluloses from being degraded. Lignin structure is unhydrolyzable, and only a few species of microorganisms are able to hydrolyze lignin [38-40]. The ability of fungi to produce lignocellulolytic enzyme activities during the biodegradation of lignocellulosic materials has been discussed by some researchers [41-44]. According to Kausar et al. [41], dark brown complexes are formed through a catalyzation reaction between polyphenol and molecular oxygen activated by the components of polyphenol oxidase: monophebol oxidase and catechol oxidase. This brown complex plays an important role in the degradation of phenol compounds in lignin. Mtui [10] briefly elaborated on the process involving oxidative conversion of organic compounds and materials named oxidases. Dioxygen $\left(\mathrm{O}_{2}\right)$ acts as the co-factor (terminal for electron acceptor) that is needed by phenol oxidases. Therefore, the development of dark brown pigments is confirmed through the polyphenol oxidase (PPO) activity by fungal isolates.

Comparative studies are conducted on the ability of all Trichoderma isolates from Sabah and Antarctic. Antarctic isolates always exhibited lower capability in degrading lignin when compared to the Sabah isolates. They produced smaller brown pigments on TAM plates. Muratov and Kim [45] have performed an experiment on the degradation of lignin by using Trichoderma viride, Trichoderma reesei, and Aspergillus niger in supercritical $\mathrm{CO}_{2}$. Similar studies have been conducted by Wu et al. [46] for P. chrysosporium, P. ostreatus and by Lozovaya et al. [47] for Fusarium solani. Nevertheless, there is a lacks of information about ligninolytic activities by other Trichoderma species.

\section{Enzymatic degradation of cellulose}

Fungi are the main cellulose-producing microorganisms. Nonetheless, only a few researchers found the microorganisms that are able to produce significant amounts of cellulase enzymes. Jahangeer et al. [48] have reported a few species of fungi, including Trichoderma reesei, Humicola sp., Penicillium sp., and Aspergillus sp. that have the ability to convert cellulose to glucose. Similar studies done by Khokhar et al. [49] reported that Trichoderma sp. exhibited the highest cellulase activity and consistency in producing cellulase when compared with Penicillium sp. and Aspergillus sp.

Carboxymethyl Cellulose (CMC) is chemically modified and used to resemble the cellulose in this research. Congo red can only colorize the cellulose and the area that is decolorized by the endoglucanases enzyme [25]. Mtui [10] specified hydrolases as the enzymes that are responsible for the catalyzation of chemical bonds by hydrolysis. For the degradation of cellulose, cellulases can be the hydrolases that catalyze cellulolytic reactions. Hydrolysis of cellulose, especially the endoglucanases enzyme, is crucial, as it initiates the next synergistic actions involving $\beta$-glucosidase and cellobiohydrolases [50].

Capability among all of the Trichoderma isolates in degrading cellulose is tested and shown in Figures 5 and 6. Antarctic Trichoderma isolates are found to exhibit lower capability in degrading cellulose toward Sabah Trichoderma isolates. As evident in the result, larger brown pigments are seen on plates containing CMC inoculated with Sabah Trichoderma isolates. According to Domsch et al. [51], by comparing all three activities, the hydrolysis of lignin exhibits lower activity while compared with cellulose and starch. On analysis of our 
Citation: Saili NS, Siddiquee S, Vui Ling CMW, González M, Vijay Kumar S (2014) Lignocellulolytic Activities among Trichoderma Isolates from Lahad Datu, Sabah and Deception Island, Antarctic. J Microb Biochem Technol 6: 295-302. doi:10.4172/1948-5948.1000159

results, similar results have been found as previously mentioned by Domsch et al. [51]. Khokhar et al. [49] stated that the isolation and screening of filamentous Trichoderma fungi have performed the highest cellulolytic activities when compared with Penicillium and Aspergillus.

Cellulose decomposition in the various Antarctic regions has been studied by some researchers $[20,22,23]$, and it has been found that cellulolytic fungi existed in the Antarctic regions and very slow rate decomposition occurred when compared with fungi in temperate environments. A similar result was found in our experimental results when testing Trichoderma isolates in tropical (Sabah) and very cold regions (Antarctic).

\section{Enzymatic degradation of starch}

Amylase enzymes are important and play key roles in the fermentation process and food industries, particularly related to starch hydrolysis. This enzyme can be produced in several microorganisms, including bacteria, fungi, as well as plants and animals. Starch is a glucose polymer that has the combination of $\alpha-1,4$ and $\alpha-1,6$ glycosidic bonds. On the basis of the facts stated by Bernfeld [52], starch is degraded by the amylases and other related polymers by hydrolyzing the glycosidic bonds between adjacent glucose units of the polymers to yield products that have characteristics of individual amylolytic enzymes.

The appearance of clearing halo zone and the absence of the blueblack indicator in the inoculation areas depict starch hydrolysis. Fungi releases $\alpha$-amylase enzyme that later cleaves the bond in starch and leaves the starch in a simple form known as amylose. The amylase enzyme has a clear halo zone [53]. Amylase activities are found to be higher in Sabah Trichoderma isolates when compared with the smaller halo zone produced by Antarctic Trichoderma isolates.

Enzymatic degradation of starch by fungi has been studied by a few researchers such as Aspergillus wentii by Johnson et al. [54]; Rhizopus sp. by Adebiyi et al. [55]; Aspergillus oryzae, Aspergillus flavus, Lichteimia sp., and Rhizopus oryzae by Kim et al. [56]; Saccharomyces cerevisiae, Aspergillus sp., Mucor sp., and Rhizopus sp by Ominyi et al. [57]; and Trichoderma sp by Kausar et al. [41].

\section{Conclusions}

Most of the Trichoderma isolates from Sabah and Antarctic have exhibited ability in hydrolyzing three important categories: lignin, cellulose, and starch. In spite of this, Sabah Trichoderma isolates are found to exhibit higher ligninolytic, cellulolytic, and amylase activities when compared with Antarctic Trichoderma isolates. The best seven Sabah Trichoderma isolates (5D, 10L2, 10E, 1gB, SICCI, SICCII, and 11B) are chosen for further experimental work similar to the fiber decomposer based on their optimum capability displayed in degrading lignin, cellulose, and starch. In future, these Trichoderma isolates in the composting process are applied as biocontrol agents in controlling disease and increasing yield of production in the agricultural industry.

\section{Acknowledgment}

These work samples were provided by the Malaysian Antarctic Research Program (MARP); the Ministry of Science, Technology, and Innovation (MOSTI) Malaysia; and Instituto Antartico Chileno (INACH), Chile. The authors would like to thank the personnel at INACH, especially Jose Retamales, Marcelo Leppe Marcelo Gonzalez, Paulina Julio Rocamora, Veronica Vallejos, Cristian Rodrigo, and Patricio Barraza, for their advice and logistic support. The authors are also pleased to acknowledge the Biotechnology Research Institute, Universiti Malaysia Sabah, for the excellent facilities and Felda Sahabat Lahad Datu for providing samples.

\section{Conflict of Interest}

All authors have agreed to submit the prepared manuscript and declare to no interest conflict of patent or stock ownership, membership of a company board of directors, membership of an advisory board or committee for a company, and consultancy for or receipt of speaker's fees from a company.

\section{References}

1. Roslan A, Muhammad Fairuz KA, Borhan AN, Mohd Arif S (2011) A study on the Malaysian Oil Palm Biomass Sector-Supply and Perception of Palm Oil Millers. Oil Palm Indust Econ J 11: 28-41.

2. EU-Malaysia Biomass Sustainable Production Initiative (2013) Biomass in Malaysia.

3. MPOB (2011) A summary on the performance of the Malaysian oil palm industry.

4. The Star Online (2012) Malaysia produced $80 \mathrm{~m}$ tonnes oil palm biomass in 2011.

5. Najafpour G, Ideris A, Salmanpour S, Norouzi M (2007) Acid hydrolysis of pretreated palm oil lignocellulosic wastes. Int J Engineer (Trans B: Applicat) 20: $147-156$

6. Ridzuan R, Shaler S, Mohd Arif J (2002) Property of Medium Density Fibreboard from Oil Palm Empty Fruit Bunch. J Oil Palm Res 14: 34-40.

7. Dayana Amira R, Roshanida AR, Rosli MI, Siti Fatimah Zahrah MF, Mohd Anuar J, et al. (2012) Bioconversion of empty fruit bunch (EFB) and palm oil mill effluent (POME) into compost using Trichoderma virens. Afric J Biotechnol 10(81): 18775-18780.

8. Mohamad Zainuddin NAI, Faridah A (2008) Disease Suppression in Ganoderma treated with Trichoderma harzianum. Plant Protect Sci 44: 101-107.

9. Siddiquee S, Umi Kalsom Y, Kausar H, Sarwar J (2009) In vitro studies on the potential Trichoderma harzianum for antagonistic properties against Ganoderma boninense. J Food Agri Environ 7: 970-976.

10. Mtui GYS (2012) Lignocellulolytic enzymes from tropical fungi: Types, substrates and applications. Sci Res Essays 7: 1544-1555.

11. Biswas DR, Narayanasamy G (2002) Mobilization of phosphorus from rock phosphate through composting using crop residue-fertilizer. News B, pp 53-56.

12. Sabah State Government (2013) About Sabah

13. Lahad Datu District Office (2013) About Lahad Datu.

14. Natural Museum History (2013) Antarctic fact file.

15. Friedmann El, Weed R (1987) Microbial trace-fossil formation, biogenous, and abiotic weathering in the Antarctic cold desert. Science 236: 703-705.

16. Holker U, Schmiers H, Grobe S, Winkelhofer M, Polsakiewicz M, et al. (2002) Solubilization of low-rank coal by Trichoderma atroviride: Evidence for the involvement of hydrolytic and oxidative enzymes by using [sup14] C-labelled lignite. J Industrial Microbiol Biotechnol 4: 207.

17. Hughes KA, Bridge P, Clark MS (2007) Tolerance of Antarctic soil fungi to hydrocarbons. Sci Total Environ 372: 539-548

18. Ren J, Xue C, Tian L, Xu M, Chen J, et al. (2009) Asperelines A-F, peptaibols from the marine-derived fungus Trichoderma asperellum. J Nat Prod 72: 1036 1044

19. Jaklitsch WM (2011) European species of Hypocrea part II: species with hyaline ascospores. Fungal Divers 48: 1-250.

20. Walton DWH (1985) Cellulose decomposition and its relationship to nutrient cycling at South Georgia. In: Siegfried WR, Condy PR, Laws RM (eds) Antarctic nutrient cycles and food webs. Springer, Berlin, pp. 192-199.

21. Pugh GJF, Allsopp D (1982) Microfungi on Signy Island, South Orkney Islands Brit Antarct Surv Bull 57: 55-67.

22. Yamamoto H, Ohtani S, Tatsuyama K, Akiyama M (1991) Preliminary repor on cellulolytic activity in the Antarctic region (extended Abstract). Proce NIPR Symposium on Polar Biology 4: 179-182.

23. Fenice M, Selbmann L, Zucconi L, Onofri S (1997) Production of extracellula enzymes by Antarctic fungal strains. Polar Biol 17: 275-280.

24. Elad $Y$, Chet I, Henis $Y$ (1981) A selective medium for improving quantitative isolation of Trichoderma spp. from soil. Phytoparasitica 9(1): 59-67. 
Citation: Saili NS, Siddiquee S, Vui Ling CMW, González M, Vijay Kumar S (2014) Lignocellulolytic Activities among Trichoderma Isolates from Lahad Datu, Sabah and Deception Island, Antarctic. J Microb Biochem Technol 6: 295-302. doi:10.4172/1948-5948.1000159

25. Thormann MN, Currah RS, Bayley SE (2002) The relative ability of fungi from Sphagnum fuscum to decompose selected carbon substrates. Can J Microbiol 48: 204-211.

26. Jensen HL (2008) Notes on the biology of Azotobacter. J Appl Microbiol 14: 89-94.

27. Teather RM, Wood PJ (1982) Use of Congo red-polysaccharide interactions in enumeration and characterization of cellulolytic bacteria from the bovine rumen. Appl Environ Microbiol 43: 777-780.

28. Marx DH, Bryan WC (1975) Growth and ectomycorrhizal development of loblolly pine seedlings fumigated soil infested with the fungal symbiont Pisolithus tinctorius. Forest Sci 21: 245-254

29. Siddiquee S, Abdullah F, Tan SG, Emilia RA (2007) Phylogenetic Relationships of Trichoderma harzianum based on the Sequence Analysis of the Internal TranscribedSpacer Region-1 of the rDNA. J Appl Sci Res 3: 896-903.

30. Sariah M, Choo CW, Zakaria H, Norihan MS (2005) Quantification and characterisation of Trichoderma spp. from different ecosystems. Mycopathologia 159: 113-117.

31. Bae H, Roberts DP, Lim HS, Strem MD, Park SC, et al. (2011) Endophytic Trichoderma isolates from tropical environments delay disease onset and induce resistance against Phytophthora capsici in hot pepper using multiple mechanisms. Mol Plant Microbe Interact 24: 336-351.

32. Krishnan A, Alias SA, Wong CMVL, Pang KL, Convey P (2011) Extracellular hydrolase enzyme production by soil fungi from King George Island, Antarctic. Polar Biol 34: 1535-1542.

33. Farrell RL, Arenz BE, Duncan SM, Held BW, Jurgens JA, et al. (2011) Introduced and indigenous fungi of the Rose Island historic huts and pristine areas of Antarctic. Polar Biol 34: 1669-1677.

34. Loperena L, Soria V, Varela H, Lupo S, Bergalli A, et al. (2012) Extracellular enzymes produced by microorganisms isolated from maritime Antarctica. World J Microbiol Biotechnol 28: 2249-2256.

35. Ali SH, Alias SA, Siang HY, Smykla J, Pang K, et al. (2013) Studies on diversity of soil microfungi in the Hornsund area, Spitsbergen. Polish Polar Res 34 : 39-54.

36. Singh SM, Puja G, Bhat DJ (2006) Psychrophilic fungi from Schirmacher Oasis, East Antarctic. Cur Sci 90: 1388-1392.

37. Johnson LF, Bernard EC, Qian P (1987) Isolation of Trichoderma spp. at Low Temperatures from Tennessee and Alaska Soils. Plant Disease 71: 137-140.

38. Haselwandter K, Bobleter O, Read DJ (1990) Utilization of lignin by ericoid and ectomycorrhizal fungi. Arch Mikrobiol 153: 352-354.

39. Hambleton S, Currah RS (1997) Fungal endophytes from the roots of alpine and boreal Ericaceae. Can J Bot 75: 1570-1581.

40. Jin R, Liao H, Liu X, Zheng M, Xiong X, Liu X, et al. (2012) Identification and characterization of a fungal strain with lignin and cellulose hydrolysis activities. Afric J Microbiol Res 6(36): 6545-6550.
41. Kausar H, Sariah M, Mohd Saud H, Alam MZ, Ismail MR (2010) Development of compatible lignocellulolytic fungal consortium for the composting of rice straw. Int Biodeter Biodeg 64: 594-600.

42. Rodrigues MAM, Pinto P, Bezerra RMF, Dias AA, Guedes CVM, et al. (2008) Effect of enzyme extracts isolated from white-rot fungi on chemical composition and in vitro digestibility of wheat straw. Animal Feed Sci Technol 141: 326-338.

43. Zhang LH, Li D, Wang LJ, Wang TP, Zhang L, et al. (2008) Effect of steam explosion on biodegradation of lignin in wheat straw. Bioresour Technol 99: 8512-8515.

44. Dinis MJ, Bezerra RM, Nunes F, Dias AA, Guedes CV, et al. (2009) Modification of wheat straw lignin by solid state fermentation with white-rot fungi. Bioresour Technol 100: 4829-4835.

45. Muratov G, Kim C (2002) Enzymatic Hydrolysis of Cotton Fibers in Supercritical $\mathrm{CO}_{2}$. Biotechnol Bioproc Engineer 7: 85-88.

46. Wu J, Xiao YZ, Yu HQ (2005) Degradation of lignin in pulp mill wastewaters by white-rot fungi on biofilm. Bioresour Technol 96: 1357-1363.

47. Lozovaya VV, Lygin AV, Zernova OV, Li S, Widholm JM (2002) Lignin Degradation by Fusarium solani f. sp. glycines. Plant Dis 90: 77-82.

48. Jahangeer S, Khan N, Jahangeer S, Sohail M, Shahzad S, et al. (2005) Screening and characterization of fungal cellulases isolated from the native environmental source. Pak J Bot 37: 739-748.

49. Khokhar I, Haider MS, Mushtaq S, Mukhtar I (2012) Isolation and screening of highly cellulolytic filamentous fungi. Scholarly J Agri Sci 2(7): 126-129.

50. Lynd LR, Weimer PJ, van Zyl WH, Pretorius IS (2002) Microbial cellulose utilization: fundamentals and biotechnology. Microbiol Mol Biol Rev 66: 506577 , table of contents.

51. Domsch KH, Gams W, Anderson TH (1980) Compendium of soil fungi. London, England: Academic Press, p 865

52. Bernfeld P (1951) Enzymes of starch degradation and synthesis. Adv Enzymol Relat Subj Biochem 12: 379-428.

53. American Society for Microbiology (2011) The starch hydrolysis.

54. Johnson DE, Nelson GE, Ciegler A (1968) Starch Hydrolysis by Conidia of Aspergillus wentii. Appl Microbiol 16: 1678-1683.

55. Adebiyi AO, Adebiyi AP, Olaniyi EO (2005) Nutritional composition of sorghum bicolour starch hydrolyzed with amylase from Rhizopus sp. Afri J Biotechnol 4(10): 1089-1094.

56. Kim HR, Kim JH, Bai DH, Ahn BH (2011) Identification and Characterization of Useful Fungi with Ît-Amylase Activity from the Korean Traditional Nuruk. Mycobiology 39: 278-282.

57. Ominyi MC, Ogbonna JC, Nwoba EG, Nwagu KE, Ukachi R (2013) Isolation and Screening of a-Amylase and Glucoamylase Producing Fungi and Their Application in Bioethanol Production. Int J Sci Nat 4: 44-50. 